\title{
Local Government Level Restorative Adjudication: An Alternative Model of Justice for Children in Bangladesh
}

Commonwealth Journal of Local Governance

Issue 4: November 2009

http:/lepress.lib.uts.edu.au/ojs/index.php/cjlg

\section{Borhan Uddin Khan}

Department of Law, University of Dhaka Bangladesh

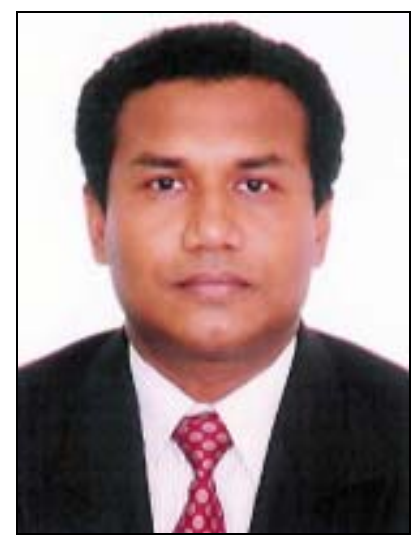

\section{Muhammad Mahbubur Rahman}

Department of Law, University of Dhaka Bangladesh

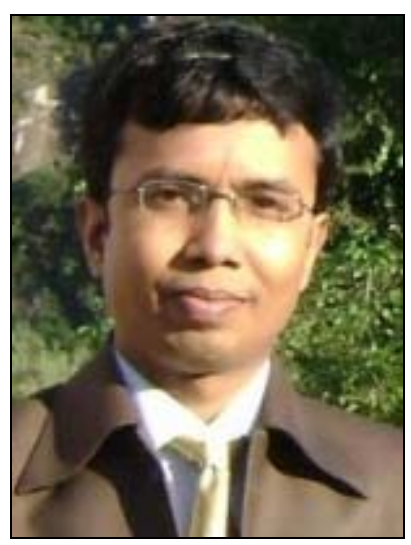

\begin{abstract}
Keeping the best interests of children in mind, this paper examines the prevailing restorative model of justice at the local government level in Bangladesh and argues that this model, if adequately activated and reformed, can be a desirable alternative to the formal system of justice for children who come into contact or conflict with the law. In doing so, the paper outlines the historical development of local government adjudication mechanisms, analyzes the existing norms and procedures of such adjudication, outlines the potential of such adjudication bodies as viable alternatives to juvenile courts in
\end{abstract}


protecting the best interests of children, sets out the shortcomings of the local government bodies and the challenges involved in capturing their potential, and finally suggests a number of ways in which the model could be improved.

Keywords: Juvenile justice; restorative justice; local government level adjudication; village courts

\section{Introduction}

A large number of children in Bangladesh are vulnerable to different forms of abuse. This vulnerability is particularly striking for children facing the adult world of law, detention and criminal justice. In fact, the prevailing justice norms and practices of Bangladesh constitute one of the most prominent areas where children are easy victims of frequent abuses (Khan and Rahman 2008, p. iii). The formal justice ${ }^{1}$ mechanism for children operates in accordance with the Children Act, 1974 (Act No. XXXIX of 1974) and the Children Rules, 1976 (S.R.O. 103-L/76). The Act establishes juvenile courts as formal adjudication bodies, although the functioning of these courts is prescribed to be very informal and child-friendly. Juvenile courts are statutorily empowered to deal with children who are in conflict with the law, children who are victims of any offence and neglected children. ${ }^{2}$ But, for many years, the true spirit of the Act was largely overlooked. True it is that, over the last few years, the judiciary seems more sensitized to the rights of such children, ${ }^{3}$ but the full realization of their rights is still a daunting challenge. Despite recent positive trends within the existing formal child justice system, the efficacy of the model is not beyond question. There are concerns, for example, about the need for societal care and protection, diversion and rehabilitation. The focus of these concerns is not to scrap the current system but to search for viable alternatives.

\footnotetext{
${ }^{1}$ In the context of this paper, the word 'justice' is meant to include not only penal justice delivered by courts to children in conflict of the law but also the care and protection offered through justice mechanisms for children in contact with the law, particularly children who are victims of any offence and neglected children. At present, the juvenile courts are empowered to deliver justice in favour of victimized and neglected children. See the Children Act 1974 (Act No. XXXIX of 1974) sections 32-33.

${ }^{2}$ Children's contact with the law is multi-dimensional. Children come in conflict with the law when they are accused of committing an offence. On the other hand, a child may come in contact with the law either as a victim or as a witness or due to some other circumstance. For more details see, Malik 2004: 1-2.

${ }^{3}$ On pro-child judicial interventions during recent years, see Khan and Rahman 2008: 113-116.
} 
In this context, restorative justice ${ }^{4}$ as dispensed by local government adjudication bodies can be a good alternative that may minimize many of the concerns stated above and advance the best interests of children. ${ }^{5}$ Restorative justice, which includes the rehabilitation of offenders, is more consistent with the philosophy of the juvenile court than with the retributive philosophy that guides the criminal justice processing of adult offenders (Rodriguez 2007, p. 356). The combination of certain formal principles of the state legal system with a more informal approach to handling disputes places these local government adjudication bodies halfway between the fully-fledged judicial institutions of the state and other entities that flourish under the auspices of communities themselves without the aid of state law (Galanter and Baxi 1979). This paper argues that local government adjudication bodies can be resorted to as alternative forums to the formal courts and thereby the rights and interests of children can be adequately safeguarded. However, the paper is not confined to substantiating the rationale for this proposition. In addition, the existing mechanisms of justice in the local government bodies are examined to identify their shortcomings and challenges with a view to finding workable solutions. In doing so, we encountered great difficulties in collecting data regarding the actual functioning of justice mechanisms at the various levels of local government in Bangladesh. There is a dearth of empirical research. Although there are some studies on village courts (World Bank 2008; Ameen 2005; Khan 1992; UNDP 2002, pp. 91-100; Rahman 1985), most of them do not present any national data. Moreover, there is hardly any study on the functioning of local government adjudication bodies in urban areas. Within these constraints, the present study, which also did not involve any field investigations, seeks to substantiate the proposition and examine the issues as stated above.

\footnotetext{
${ }^{4}$ Restorative justice is a way of looking at behavior that harms through a different lens. Instead of viewing it from the traditional retributive justice perspective, the new lens focuses on the harm to the victim and how to repair that harm. The offender takes responsibility for the harm he/she caused and makes amends. The community supports the victim while holding the offender accountable for the harm. Communities examine the conditions that might have caused the harm and then find ways to change those conditions so that the likelihood of harm is reduced in the future (Zehr 1990; Johnstone 2003; McLaughlin et al. 2003; McEvoy and Newburn 2003; Weitekamp and Kerner 2002).

${ }^{5}$ On the principle of 'best interests of children', see, Alston and Walsh 1996; Alston 1994; Walker 1998.
} 


\section{History of Local Government Adjudication}

Although during recent years restorative justice has become a truly global concept, its efficacy in a particular jurisdiction depends on many local factors, notably public awareness. In fact, lack of familiarity may impede public acceptance of restorative justice (Roberts and Stalans 2004, p. 318). In this respect, Bangladesh is well-placed: the history of local government adjudication bodies conveys a clear message that the system of local adjudication outside the fully-fledged formal court structure is not a novel concept in Bangladesh and already enjoys public acceptance.

Bangladesh has a long history of informal dispute resolution mechanisms. Throughout the ages, these mechanisms were not statutorily recognized. However, the introduction of local government bodies paved the way for a statutory form of quasi-formal adjudication. The Village Chaukidari Act, 1870 (Bengal Act 6 of 1870) was the first Act to introduce a local institution at the village level in Bengal (Bari 1996, p. 3). It empowered the District Magistrate to appoint a panchayat consisting of three to five nominated members for each village (section 3). Although this institution was not empowered to adjudicate any dispute, petty cases could be settled by it with the mutual consent of the parties involved (Wahhab 2009, p. 19). The first proposal for establishment of village level courts on a legal basis was made by the Fraser Commission Report, 1902-03. Later on, the Hobhouse Commission of 1907-09 and Levinge Committee of 1913 proposed creation of village level courts to handle minor cases amongst the village people (Ameen 2005, p. 110). Accordingly, the Bengal Village Self-Government Act, 1919 (Bengal Act V of 1919) was passed. This was the first law to empower a local government body to adjudicate criminal cases (Rahman 1985, p. 175). The Act established a 'union bench', corresponding to the present day village court, with concurrent jurisdiction ${ }^{6}$ with formal criminal courts for trying petty criminal cases.

On the other hand, in urban areas no clear pattern of municipal administration emerged until the 1840s (Siddiqui 1995, p. 146). Act X of 1842 established the first formal municipal organization. Under this Act, a town committee could be set up, upon application by two-thirds of the townspeople, by the District Magistrate. However, no

\footnotetext{
${ }^{6}$ For constitution and jurisdiction of union bench, see sections 65-66.
} 
such committee was set up in the areas now comprising Bangladesh. ${ }^{7}$ Later on, experiments were carried out through Act XXVI of 1850, and the Bengal Municipal Acts of 1864 and 1876. As a result, by the 1870s every important town of Bengal had become a municipality. ${ }^{8}$ However, there was no popular representation in these municipalities. Such representation was introduced, although on a limited scale, for the first time by the Bengal Municipal Act, 1884. By the 1890s, administration by elected committees came to be regarded as the natural form of municipal government (Siddiqui 1995, p. 146). In 1920, the government set up the Simon Commission to look into the affairs of urban local government. On the basis of recommendations made by this Commission, the Bengal Municipal Act, 1932 (Bengal Act XV of 1932) was enacted as a comprehensive code for municipal bodies. However, during British rule, urban local government bodies were not given the power to adjudicate any criminal case.

During the Pakistan period, the then existing local government structures and powers were not substantially altered until 1959. The Bengal Village Self-Government Act, 1919 (Bengal Act V of 1919) was repealed by the Basic Democracies Order, 1959 (P.O. No. 18 of 1959). Thus the local government level adjudication mechanism introduced by the 1919 Act was abolished. In 1961, the Conciliation Courts Ordinance (Ordinance No. XLIV of 1961) was promulgated. This Ordinance empowered the 'union council' (local government) to deal with minor cognizable offences (section 3). The definition of 'union council' as prescribed by this Ordinance included both union (rural) committees and town committees. ${ }^{9}$ Accordingly, a local government level adjudication system was introduced in urban areas.

The local government level adjudication system established by the 1961 Ordinance continued until the promulgation of the Village Courts Ordinance, 1976 (Ordinance No. LXI of 1976), which repealed the 1961 Ordinance (section 20). Although the Village Courts Ordinance established village courts for rural areas, the need for such a mechanism in urban areas was ignored. Subsequently, however, the enactment of the Conciliation of Disputes (Municipal Area) Ordinance, 1979 (Ordinance No. V of 1979),

\footnotetext{
${ }^{7}$ Under this Act, a town committee was set up only in Serampore. But the townspeople protested it and successfully sued the District Magistrate in the court for damages. See Siddiqui 1995: 146.

8 The earliest municipalities of Bangladesh were Nasirabad (1856), Sherpore (1861), Dhaka (1864), Chittagong (1864) and Brahmanbaria (1868). See Siddiqui 1995: 146.

${ }^{9}$ For definition of 'union council' see section 2 (i).
} 
did establish an urban counterpart of village courts. Later, the Village Courts Ordinance of 1976 and the Conciliation of Disputes (Municipal Area) Ordinance of 1979 were repealed and replaced by the Village Courts Act, 2006 (Act No. 19 of 2006) and the Disputes Conciliation (Municipal Areas) Board Act, 2004 (Act No. 12 of 2004) respectively.

\section{Justice Mechanisms within Local Government Bodies: Existing Norms and Procedures}

Today, the law recognizes two forums within local government that can adjudicate criminal cases. These are (a) village courts for rural areas which are within the limits of a union parishad $^{10}$; and (b) dispute conciliation boards for municipal areas which are within the limits of a paurashava. ${ }^{11}$ Legally mandated, these mechanisms are headed by local government personnel who dispense justice with the aid of nominees of the parties to the dispute (Khair 2008, p. 104). This section provides a brief overview of the existing norms and procedures of the two mechanisms, and then these norms and procedures are analyzed against the basic principles of the concept of restorative justice.

\section{Village Courts}

The village court is an ad hoc forum for adjudicating minor disputes or conflicts in rural areas. The Village Courts Act, 2006 (Act No. 19 of 2006) and the Village Courts Rules, $1976^{12}$ regulate the formation, jurisdiction and functioning of this forum. On application of any party to any dispute or conflict, the chairman of the union parishad concerned can form a village court (section 4(1)). A village court is composed of the chairman of the union parishad and four representatives - two from each party, one of them being a member of the parishad (section 5(1)). Ordinarily, the chairman of the union parishad acts as the chairman of the court, but where he is, for any reason, unable to act or his

\footnotetext{
${ }^{10}$ Union Parishad is the local government institution in rural areas, established by the Local Government (Union Parishads) Ordinance, 1983 (Ordinance No. LI of 1983)

${ }^{11}$ Paurashava is the local government institution in urban areas, established by the Paurashava Ordinance, 1977 (Ordinance No. XXVI of 1977)

12 S.R.O. 352-L/76 dated 15th December 1976. This was a delegated legislation made by the President of Bangladesh in exercise of the powers conferred by section 19 of the Village Courts Ordinance, 1976 (Ordinance No. LXI of 1976). Although the 1976 Ordinance is repealed by the Village Court Act, 2006 (Act No. 19 of 2006), this piece of delegated legislation is saved and accordingly operative until new Rules are made under the 2006 Act. See, The Village Court Act, 2006 (Act No. 19 of 2006), section 21 (2) (b).
} 
impartiality is questioned by any party to the dispute, any member of the parishad can act as chairman (section 5(2)).

Village courts have exclusive jurisdiction to try all disputes that are enumerated in a schedule to the Act (section 3(1)). Accordingly, taking cognizance or holding a trial of any of these offences by any criminal court is illegal and without jurisdiction. Even when the parties to a dispute seek to have one of these offences tried by a criminal court and thus bypass the village court, the criminal court cannot assume jurisdiction. However, if the chief judicial magistrate in the district is of opinion that a case triable by and pending before a village court should be tried in a criminal court in the public interest and that of justice, he may withdraw that case from the village court (section 16(1)). Similarly, a village court may forward a case to the criminal court for trial and disposal if it is of the opinion that the accused deserves punishment in the interests of justice (section 16(2)). While village courts are a formally constituted judicial forum, their functioning is only semi-formal since the technical rules of procedure, as prescribed by the Code of Criminal Procedure (Act V of 1898) and the Evidence Act (Act I of 1872) are not applicable (section 13(1)). Moreover, the whole procedure is conducted without any legal practitioners (section 14).

The only adjudication option open for village courts is to order compensation of an amount not exceeding 25,000 taka (about US \$360), payable to an aggrieved person (section 7(1)). If the decision of a village court is unanimous or by a majority of $4: 1$ (or $3: 1$ if the decision is reached in the presence of only four members of the court), the decision shall be binding on the parties (section 8(1)). But, if the decision is by a majority of 3:2, any party to the dispute may, within thirty days of the decision, appeal to any judicial magistrate of the first class having jurisdiction over the case (section 8(2)(a)). The said magistrate may, if satisfied that the village court failed to render justice, set aside or modify the decision or refer the case back to the village court for reconsideration (section $8(3)$ )

\section{Dispute Conciliation Boards}

In every paurashava, there is a dispute conciliation board. The Disputes Conciliation (Municipal Areas) Board Act, 2004 (Act No. 12 of 2004) regulates the formation, jurisdiction and functioning of this adjudication body. The boards are structured and 
operate in the same way as village courts, and have exclusive jurisdiction to try all disputes specified in the schedule to the Act (section 4(1)). The list of offences is the same as that triable by village courts. However, commission of any of these offences by a person who had earlier been convicted for any cognizable offence falls outside the jurisdiction of the boards (section 4(2)(a)). Also, if an offence amenable to the jurisdiction of a board is committed along with another offence not amenable to its jurisdiction and joint trial becomes necessary, the board shall not exercise its jurisdiction to try the offence (section 5(1)). As in the case of village courts, the boards cannot pass any order of imprisonment or fine. The only adjudication option is the order of compensation (section 9(1)).

\section{Restorative Elements in Village Courts and Dispute Conciliation Boards}

Although the essential components of restorative justice are yet to be universally agreed, there are some basic principles and assumptions upon which the concept is built. One of the most fundamental of these principles and assumptions is that crime is not only a violation of penal laws, but also a violation of people and relationships (Zehr 1990). The most appropriate response to crimes, therefore, is not to punish the offender but to repair the harm caused by crimes (Latimer et al 2005, p. 128). This need for repairing the harm demands an active voice, not merely as a witness, for those most closely affected by crimes - the victims, the community, and even the offenders. Based on these premises, the concept of restorative justice seeks to create opportunities for victims, offenders and community members to meet and discuss the crime and its aftermath (Shekhar 2002, p. $60)$.

Existing norms and procedures of justice mechanisms within local government bodies in Bangladesh, as outlined above, largely reflect this fundamental principle of restorative justice. The rules regarding the constitution of village courts and dispute conciliation boards mean that justice is delivered in these forums by community members, not professional judges. The victims and offenders have an active role and right to participate in the choice of the adjudicators, since the parties themselves nominate four out of the five members of these forums. Also, the rules regarding decision-making mean that a decision against a party cannot be conclusive and remains open to appeal unless at least one of the two adjudicators nominated by him pronounces a verdict against him. This aspect of the adjudication is intended to infuse a sense of ownership of the parties in the 
decision-making process. Non-application of technical laws of procedure and evidence, and the absence of professional lawyers, also create a space for the community to apply, to a great extent, community sentiments and values in the adjudication process. The most obvious reflection of the concept of restorative justice in these mechanisms is its sole adjudication option - the order of compensation, not even a 'fine' let alone imprisonment.

\section{Local Government Bodies as Alternatives to Juvenile Courts}

The evidence suggests that a restorative model of justice works better for juveniles than it does in the case of adult offenders and provides an appropriate alternative to existing mechanisms found within the juvenile court system (Miers 2004, p. 23; Braithwaite 1999; Bazemore and Umbreit 1995; Umbreit and Coates 1992). Keeping this empirical finding in mind, if the local government bodies are reasonably empowered to deal with cases concerning children in conflict or contact with the law, and the existing mechanisms are suitably activated and reformed, there could be significant advantages over current practices. The following paragraphs elaborate these advantages.

\section{Minimizing Evil Effects of Traditional Shalish}

Traditionally, people in Bangladesh settle a good number of offences through the nonformal method of shalish, ${ }^{13}$ which is more accessible in our social context and plays a central role in conflict resolution, particularly in rural areas. The positive aspect of this conflict resolution mechanism is that it involves the community in the process and very often ends in reconciliation.

However, its traditional working has been changed over the years on various socioeconomic and religious grounds. In the absence of specified law, process and accountability, shalish has become a vehicle for imposing subjective justice by the socially, economically or religiously powerful (Biswas 2008). Sometimes, persons found 'guilty' are inflicted with humiliating, degrading or inhuman punishments. Risks are

\footnotetext{
${ }^{13}$ Shalish is a social system for informal adjudication of petty disputes, both civil and criminal, by local notables such as matbars (leaders) or shalishkars (adjudicators). It may involve voluntary submission to arbitration (which involves the parties agreeing to submit to the judgment of a shalish panel), mediation (in which the panel helps the disputants to try to devise a settlement themselves) or a blend of the two. In a harsh, extreme version of its traditional form, however, shalish instead constitutes a de facto criminal court that inflicts trial and punishment on individuals who have not consented to its jurisdiction.
} 
higher if the victim of such punishments is a child. Although inflicting punishment by way of shalish is unlawful, it cannot be uprooted overnight. Since shalish is popular for easy access and community involvement, it can only be replaced by a semi-formal legally recognized mechanism having similar advantages. In this regard, village courts or dispute reconciliation boards can be good alternatives. But unless these local bodies are empowered to deal with minor disputes to a greater extent, informal shalish is likely to extend beyond the legally specified realm and expose its evil effects.

\section{Involving the Community in Child Justice}

In many parts of the world, involvement of the community in child justice has demonstrated positive results (O’Brien 2009; Roberts 2005, pp. 147-162; Morris and Maxwell 2003; McCold 2001; McGarrell 2000; Shoemaker 1996). Unless such involvement is ensured, the existing children's justice system of Bangladesh may be viewed negatively. People at large may think that the justice system is unduly compromising public safety in the name of protecting children's interests. Such an impression, in the long run, will hinder the sustainable child-friendly development of our formal justice system. On the other hand, community participation in handling children in conflict with the law may substantially reduce the number of such children. ${ }^{14}$ If the village courts or dispute conciliation boards are empowered and activated to deal with such children, local people could be expected to render service towards the children similar to the role of probation officers.

By actively involving families and communities in the process of adjudication, village courts or dispute conciliation boards can also successfully address the underlying problems that emerge as crime, rather than continuing the criminal justice system's focus on the offenders only. ${ }^{15}$ Recourse to these bodies for dealing with children in conflict or contact with the law further ensures that the values of the community are taken into consideration when addressing a particular social problem. This infuses in the minds of the people a sense of ownership, not only in respect of the adjudication process but also in respect of the children dealt with by the process. Moreover, adjudication by these

\footnotetext{
${ }^{14}$ There are a good number of studies finding that restorative justice decreases the problem of recidivism (Latimer et al 2005; Hayes and Daly 2003; Maxwell and Morris 2001; Sherman et al 2000).

${ }^{15}$ On how this aspect of restorative justice can lead to community development on a number of levels, see Ness 1999: 264.
} 
bodies ensures that such children are kept close to their families and consequently the chances for their re-integration into society are enhanced.

\section{Promoting Diversion and Rehabilitation}

Entry into the formal justice system can be traumatic and can stigmatize an adolescent. It should therefore be avoided whenever the matter can be adequately dealt with in a less formal way (UNICEF 2004, p. 130). Instead of depriving children of liberty, the Convention on the Rights of the Child (G.A. res. 44/25, annex, 44 U.N. GAOR Supp. (No. 49) at 167, U.N. Doc. A/44/49 (1989)) urges States to "seek to promote ... measures for dealing with such children without resorting to judicial proceedings" (Article 40(3)(b)). But in Bangladesh we have no nation-wide programme to divert children away from the formal court system, either at the time of arrest or during the early stages of the court process. Institutionalization, both in law and in practice, is the primary tool used to rehabilitate children in conflict with the law, regardless of the seriousness of the offence committed (Khan and Rahman 2008, p. 129).

It appears, however, that there are three discretionary options of diversion in the existing child justice system. Firstly, the police as well as the court can grant bail in favour of a child accused. Secondly, at the adjudication stage, the court can pass an order of admonition or probation under section 53(1) of the Children Act. ${ }^{16}$ Thirdly, at the posttrial institutionalisation stage, the government can order early release of children detained under section 67(1) of the Children Act. ${ }^{17}$ It is true that during recent years children in conflict with the law have been graced with bail in greater numbers than before. But there is no record of passing orders of admonition or probation. The power of the government under section 67(1) is also hardly exercised. So far, only three children have been released under this section. This being the scenario, securing the best interests of children alleged to have committed an offence is a challenging issue under the existing

\footnotetext{
${ }^{16}$ Section 53 (1) of the Children Act 1974 (Act No. XXXIX of 1974) reads: "A Court may, if it thinks fit, instead of directing any youthful offender to be detained in a certified institute under section 52, order him to be (a) discharged after due admonition, or (b) released on probation of good conduct and committed to the care of his parent or guardian or other adult relative or other fit person on such parent, guardian, relative or person executing a bond, with or without sureties, as the Court may require, to be responsible for the good behaviour of the youthful offender for any period not exceeding three years, and the Court may also order that the youthful offender be placed under the supervision of a Probation Officer.
} 
formal justice mechanism. Hence, we should look forward not only to better use of diversion options available under the Children Act 1974 but also to going beyond these limited prescriptions, especially for children accused of minor offences.

Although there has been much talk about reducing reliance on institutionalization, to date there has been limited investment in developing the necessary alternatives. This is because at all stages institutionalization is the easiest option (Khan and Rahman 2008, p. 130). Consequently, in our formal justice practices, recourse to deprivation of the liberty of children is too frequent an occurrence. Children committed to institutions established by both government and non-government organizations are not receiving mainstream education. Moreover, the training imparted to them has no market value. Therefore institutionalization is not supportive for children, rather this practice is contributing to the growth of a huge unproductive mass that will ultimately transform into a major burden for society. To overturn this situation, we need diversion and rehabilitation through community based adjudication bodies. Such a movement towards diversion and rehabilitation is likely to be more successful under local government elected bodies, since in village courts or dispute conciliation boards the community leadership role of the adjudicators can be expected to guide them to realize that their function is not only to punish the child offenders, but also to assist them in the re-integration process.

\section{Ensuring Better Parental Care}

Lack of parental care leads many children to be in conflict with the law. Moreover, a good number of children are abandoned or become victims of offences perpetrated by adults only because they fail to receive proper parental care. To prosecute any child who is in conflict with the law due to lack of parental care through the formal justice mechanism is to ignore the need to protect the 'best interests' of children. Since formal justice adjudication usually focuses on acquittal or conviction , the issue of parental care is largely ignored. In this context, adjudication by local government bodies can be a good option to explore. Village courts or dispute conciliation boards cannot pass any sentence. They can, at most, order the payment of compensation to an aggrieved party. Therefore, if a child in conflict with the law is tried before these forums, parents, being the guardian of child, have to face the risk of paying compensation. This aspect of adjudication may

\footnotetext{
${ }^{17}$ Section 67(1) of the Children Act 1974 (Act No. XXXIX of 1974) reads: "The Government may, at any time, order a child or youthful offender to be discharged from a certified institute or
} 
make them more cautious in preventing their children from being in conflict with the law. Similarly, if these local bodies were equipped with a care and protection mechanism for children in contact with the law, accountability of parents could be guaranteed more effectively since local adjudicators are more able to judge the level of care and protection a child receives from his/her parents. Moreover, local government level adjudication has the potential to engender community pressure to ensure better parental care that will not only keep children away from conflict or contact with the law but also ensure better care and protection of such children in their family environment. ${ }^{18}$

\section{Ensuring Speedy Delivery of Cost-effective Justice}

As stated earlier, empirical research on local government adjudication bodies in Bangladesh is insufficient to draw any confident conclusion about the practical realities of their operations. However, research carried out in other jurisdictions in respect of similar adjudication bodies suggests that, compared with traditional formal courts, they can provide immediate resolution and cost effective justice (Sivakumar 2003; Klock 2001; Mathur 1997). Studies, although very few in number, carried out so far on the functioning of village courts in Bangladesh endorse this suggestion. One such study concludes that village courts settle disputes at minimum cost and trouble (Rahman 1985: Solaiman 1981). Another reveals that village courts save people from harassment by the touts and the cost of legal practitioners (Khan 1992). These findings regarding village courts indicate that people have better access to justice before local government adjudication bodies - they get cost effective justice and quick resolution before petty disputes turn into bigger problems (Wahhab 2009, p. 24).

\section{Potential Shortcomings and Challenges}

As outlined above, the existing norms and procedures of local government adjudication bodies reveal some positive aspects that can be beneficial for children. However, despite these child-friendly attributes, both legal standards and aspects of practice suggest some shortcomings and pose some challenges that must be properly addressed if children are to be dealt with by local government adjudication bodies in greater number and with proper care and protection.

approved home, either absolutely or on such condition as the Government may specify.” ${ }^{18}$ In fact, any sensitive restorative approach can give families an opportunity to take and share responsibility with and for their young people and to do something positive about offending. See, Whyte 2004: 6. 


\section{Limited Coverage}

At present, only two types of local government adjudication bodies are legally authorized to deliver restorative justice: village courts within the limits of union parishad and dispute conciliation boards within the limits of paurashava. Areas covered by city corporations and cantonment boards are outside the purview of local government adjudication.

\section{Limited Jurisdiction}

The list of offences currently subject to the jurisdiction of village courts and dispute conciliation boards is unreasonably short. Moreover, the choice of offences reflects no rational basis. It contains several cognizable offences, some of which are of a serious nature, but fails to contain many non-cognizable petty offences. This anomaly needs to be rectified. Further, section 16 of the Village Courts Act, 2006 as well as section 5(2) of the Dispute Conciliation (Municipal Areas) Board Act, 2004 allow transfer of cases from local government adjudication bodies to the formal criminal courts in the 'interests of justice'. Any such transfer of a case wherein a child is accused can cause double trouble to the accused and thus jeopardize the 'interests of children'. Another area of concern is joinder of offences in a case. The Dispute Conciliation (Municipal Areas) Board Act of 2004 expressly provides that if an offence amenable to the jurisdiction of the board is committed along with another offence not amenable to its jurisdiction and joint trial becomes necessary, the board shall not exercise its jurisdiction to try the offence (section 5(1)). Although the Village Courts Act of 2006 does not contain any such provision, it has been held by the highest court of the country that if in a case, an offence triable by the village court is joined with an offence triable by the magistrate, the case shall be tried by the magistrate and not by the village court (Abul Kalam and others, vs. Abu Daud and another, 4 MLR (AD) (1999) 414 = 5 BLC (AD) (2000) 19). Thus a child committing any offence within the jurisdiction of local government adjudication bodies can easily be forced to face formal courts by mere allegation of another offence outside those bodies' jurisdiction. 


\section{Power of the Police to Investigate Cognizable Offences}

As note above, village courts and dispute conciliation boards are authorized to deal with some cognizable offences. ${ }^{19}$ In the case of these offences, police retain the power to investigate (The Village Court Act, 2006 (Act No. 19 of 2006), section 17; The Disputes Conciliation (Municipal Areas) Board Act, 2004 (Act No. 12 of 2004), section 18). Therefore, since the power of investigation, so far as cognizable offences are concerned, includes the power to arrest an accused without the authorization of any court (Code of Criminal Procedure 1898 (Act V of 1898), section 156), there is the possibility that a child accused of any of those offences can be arrested by the police.

\section{No Special Treatment for Children}

One of the shortcomings of the Village Courts Act 2006 and Dispute Conciliation (Municipal Areas) Board Act, 2004 is that these two Acts do not differentiate a child accused from an adult accused in terms of their treatment. The union bench established by the Bengal Village Self-Government Act, 1919 was authorized to release an offender after due admonition or on probation considering his conviction record, age, character, and antecedents (section 72A). Also, a child, if tried or dealt with by the formal courts in accordance with the Children Act, 1974, can be released after due admonition or on probation (section 53(1)). But these two adjudication options, admonition and probation, are not available to local government bodies.

\section{Care and Protection of Destitute and Neglected Children}

Part V of the Children Act, 1974 (Act No. XXXIX 1974) empowers the juvenile courts to take necessary measures in respect of destitute and neglected children (sections 3233). However, this jurisdiction of the juvenile courts is rarely exercised. In fact, societal aspects of the issue of care or protection of destitute and neglected children are not easy matters for the formal courts to address in a successful manner. As an alternative, therefore, vesting this power in the local government adjudication bodies could be a good option. However, at present these adjudication bodies are not so empowered.

\footnotetext{
${ }^{19}$ For definition and categorization of 'cognizable offence', see The Code of Criminal Procedure, 1898 (Act V of 1898), section 4(1)(n) read with column 3, schedule II. Cognizable offences amenable to the jurisdiction of village courts and dispute conciliation boards are the offences that are punishable under sections 143, 147, 341, 342, 379, 380, 381, 406, 420, 428, 429, and 447 of the Penal Code, 1860 (Act XLV of 1860)
} 


\section{Malfunctioning and Non-functioning}

The preoccupation of local government bodies with issues other than dispute resolution, especially service delivery, has gradually diverted their focus from dispensing justice (Khair 2001). Consequently, village courts have now in most cases disappeared. This leaves the traditional informal shalish as the dominant means of adjudication for smallscale civil and criminal disputes (Lewis and Hossain 2005, pp. 19-20). An opinion survey ${ }^{20}$ conducted by Democracywatch reveals that regarding village courts, only $6.8 \%$ of the respondents said they were functioning, $71.0 \%$ said they were beset with favouritism, and 22.2\% said they were inactive (People's Reporting Centre 2007). Research carried out in three districts ${ }^{21}$ found that village courts started functioning only when the Madaripur Legal Aid Association (MLAA), a non-government organisation, stepped in as facilitator (Ameen 2005, p. 116). It is widely held that, outside of MLAA's coverage area, village courts are largely defunct (Hassan 2006; Lewis and Hossain 2005; Bode 2002).

Similarly, village courts do not appear to have attracted significant community support (Khair 2008, p. 127). One study on several village courts found that only twenty percent of cases within their jurisdiction actually reach these courts (Quader 2005, p. 23), while findings from a participatory rural appraisal conducted under a UNDP study in a village in Tangail district revealed a strong preference for shalish compared to the village court (UNDP 2002).

The fact that village courts or conciliation boards are expected to discharge judicial functions and administer justice in accordance with law requires that personnel serving on the adjudication panel have basic legal training. However, at least one study shows that village court functionaries lack knowledge about the procedure and norms prescribed for village courts (Khan 1992). It also found that the casual nature of shalish, which had been followed for many years, is still being practiced (Ameen 2005, p. 117). Another study shows that the village court functionaries are not serious about the working of the village courts (Khan 1992).

\footnotetext{
${ }^{20}$ Under this survey, opinion of 2500 people from 28 unions were taken.

${ }^{21}$ Madaripur, Shariatpur and Gopalgonj.
} 


\section{Conclusion}

Restorative justice can be seen as a 'care' (or feminine) response to crime in comparison to a 'justice' (or masculine) response. This is why this form of justice, particularly for dealing with children, is gaining increasing acceptability in different jurisdictions. Since the local government level adjudication bodies in Bangladesh have been designed to render restorative justice, making greater use of them should prove conducive to ensuring the best interests of children. True it is that for serious criminal matters, recourse to formal courts is the only available option. But for many offences, the reactivating of the judicial functions of the village court and the conciliation board could provide local communities with a viable alternative for dispute resolution (Khair 2004, p. 92). Similarly, empowerment of these local bodies could, to a large extent, mitigate the suffering of children in need of care and protection. However, engaging and empowering local government level adjudication bodies to deal with cases concerning children, as advocated in this paper, cannot be successful in isolation. It must be seen as a part of broader societal response to the need for child protection.

The local government level restorative adjudication system has been largely overlooked for many years. To make it a truly workable alternative model of justice for children in conflict or contact with the law, consideration would need to be given to a number of improvements. These would include extending the system to areas within the limits of city corporations and cantonment boards; giving local government level adjudication bodies the power to release a child offender after admonition or on probation, if necessary; expanding the list of offences under their jurisdiction so that, so far as accused children are concerned, they can deal with all offences punishable with imprisonment not exceeding five years; and increasing awareness and understanding amongst the relevant authorities across the country about the value of quasi-formal local government level adjudication in general, and the rights of children in conflict or contact with the law in particular. 


\section{References:}

Alston, P 1994, 'The Best Interests Principles: Towards a Reconciliation of Culture and Human Rights', International Journal of Law, Policy and the Family, vol. 8(1), pp. 1-25.

Alston, P and Walsh, B G 1996, The Best Interests of the Child: Towards a Synthesis of Children's Rights and Cultural Values, UNICEF Innocenti Research Centre, Florence.

Ameen, N 2005, 'Dispensing Justice to the Poor: The Village Court, Arbitration Council vis-à-vis NGO Mediation', Journal of the Faculty of Law, The Dhaka University Studies, Part - F, Vol. 16 (2), pp. 103-122.

Bari, M E 1996, 'Local Government Institution At the Thana/Upazila Level in Bangladesh', Journal of the Faculty of Law, The Dhaka University Studies, Part - F, Vol. VII (1), pp. 123.

Bazemore, G and Umbreit, M S 1995, 'Rethinking the Sanctioning Function in Juvenile Court: Retributive or Restorative Responses to Youth Crime', Crime \& Delinquency, vol. 41(3), pp. 296-316.

Biswas, Z I 2008, 'The Village Court: A Neglected but Potential Justice Forum', in Law and Our Rights Section, The Daily Star, Bangladesh, Issue No. 79, August 1.

Bode, B 2002, In Pursuit of Power: Local Elites and Union-Level Local Governance in Rural Northwestern Bangladesh, Care Bangladesh, Dhaka.

Braithwaite, J 1999, 'Restorative Justice: Assessing Optimistic and Pessimistic Accounts', Crime and Justice, vol. 25, pp. 1-127.

Galanter, M and Baxi, U 1979, 'Panchayat Justice: An Indian Experiment in Legal Justice', in Cappelletti, M and Garth, B (eds.), Access to Justice: Emerging Issues and Perspectives, vol. III, Guiffre, Milan, pp. 341-386.

Hassan, M 2006, Access to Formal and Informal Justice System and Legal Empowerment Strategies in Bangladesh, background paper for the Bangladesh Gender Assessment, World Bank, Dhaka.

Hayes, H, and Daly, K 2003, 'Youth Justice Conferencing and Re-offending', Justice Quarterly, vol. 20(4), pp. 725-764.

Johnstone, G 2003, A Restorative Justice Reader: Texts, Sources, Context, Willan Publishing, Devon.

Khair, S 2008, Legal Empowerment for the Poor and the Disadvantaged: Strategies, Achievements and Challenges, Dhaka.

Khair, S 2004, 'Alternative Dispute Resolution: How It Works In Bangladesh', Journal of the Faculty of Law, The Dhaka University Studies, Part - F, Vol. 15(1), pp. 119-132.

Khair, S 2001, Alternative Approaches to Justice: A Review of ADR Initiatives under the Democracy Partnership, The Asia Foundation, Dhaka.

Khan, B U and Rahman, M M 2008, Protection of Children in Conflict with the Law in Bangladesh, Save the Children UK, Dhaka.

Khan, M A 1992, 'Working of Village Courts in Four Union Parishads in Bangladesh - A Case Study', seminar paper submitted to BPATC at the 16th Senior Staff Course, October 7 December 20, Dhaka.

Klock, K A 2001, 'Resolution of Domestic Disputes through Extra-Judicial Mechanisms in the United States and Asia: Neighborhood Justice Centers, the Panchayat, and the Mahalla', Temple International \& Comparative Law Journal, vol. 15, pp. 275-295.

Latimer, J et al 2005, 'The Effectiveness of Restorative Justice Practices: A Meta-Analysis', The Prison Journal, vol. 85(2), pp. 127-144. 
Lewis, D and Hossain, A 2005, An Analysis of the Local Power Structure in Bangladesh with an Emphasis on Faridpur and Rajbari Districts, Report for SIDA, Dhaka.

Malik, S 2004, The Children Act, 1974: A Critical Commentary, Save the Children UK, Dhaka.

Mathur, S N 1997, Nyaya Panchayats As Instruments of Justice, Concept Publishing Company, New Delhi.

Maxwell, G, and Morris, A 2001, 'Family Group Conferences and Re-offending', in Morris, A \& Maxwell, G (eds.), Restorative Justice for Juveniles: Conferencing, Mediation and Circles, Hart Publishing, Oxford, pp. 243-263.

McCold, P 2001, 'Primary Restorative Justice Practices', in Morris, A and Maxwell, G (eds.), Restorative Justice for Juveniles, Hart Publishing, Oxford, pp. 41-58.

McEvoy, K and Newburn, T 2003, Criminology, Conflict Resolution and Restorative Justice, Palgrave Macmillan, New York.

McGarrell, E F et al 2000, Returning Justice to the Community: The Indianapolis Juvenile Justice Experiment, Hudson Institute, Indianapolis.

McLaughlin, E et al (eds.) 2003, Restorative Justice: Critical Issues, Sage Publications Ltd, London.

Miers, D 2004, 'Situating and Researching Restorative Justice in Great Britain', Punishment and Society, vol. 6(1), pp. 23-46.

Morris, A and Maxwell, G 2003, 'Restorative Justice in New Zealand', in Hirsh, A Von, et al (eds.), Restorative Justice and Criminal Justice, Hart Publishing, Oxford, pp. 257-271.

Ness, D W V 1999, 'Legal Issues of Restorative Justice', in Walgrave, L and Bazemore, G (eds.), Restorative Juvenile Justice: Repairing the Harm of Youth Crimes, International Network for Research on Restorative Justice for Juveniles, New York, pp. 263-284.

O’Brien, S et al 2009, 'Bringing Justice Back to the Community', Juvenile and Family Court Journal, vol. 54(3), pp. 35-46.

People’s Reporting Centre 2007, Democracywatch Bulletin, viewed 17 May 2008, $<\underline{\text { www.dwatch- }}$ bd.org/prc/html/bulletin_may.pdf>.

Quader, M A 2005, The Functioning of Village Courts in Bangladesh, Bangladesh Academy for Rural Development, Comilla.

Rahman, M M 1985, 'A Study of Two Village Courts', The Journal of Local Government, Vol. 14(2), pp. 174-188.

Roberts, A R (ed.) 2005, Juvenile Justice Sourcebook: Past, Present and Future, Oxford University Press, 2005, New York.

Roberts, J V and Stalans, L J 2004, 'Restorative Sentencing: Exploring the Views of the Public', Social Justice Research, vol. 17(3), pp. 315-334.

Rodriguez, N 2007, 'Restorative Justice at Work: Examining the Impact of Restorative Justice Resolutions on Juvenile Recidivism’, Crime \& Delinquency, vol. 53(3), pp. 355-379.

Shekhar, B 2002, 'Restorative Justice - An Alternative to Existing Retributive Justice System', Social Defence, vol. 53(152), pp. 56-74.

Sherman, L et al 2000, Recidivism Patterns in the Canberra Reintegrative Shaming Experiments, Australian National University Centre for Restorative Justice, Canberra.

Shoemaker, D J and Austin, W T 1996, 'The Republic of the Phillipines', in Shoemaker, D J (ed.), International Handbook on Juvenile Justice, Greenwood Publishing, Westport, pp. 240252.

Siddiqui, K (ed.) 1995, Local Government in South Asia - A Comparative Study, University Press Limited, Dhaka. 
Sivakumar, S 2003, 'Access to Justice: Some Innovative Experiments in India', Windsor Yearbook of Access to Justice, vol. 22, pp. 239-250.

Solaiman, M 1981, 'The Village Courts: A Study of Two Union Parishads', The Local Government Quarterly, vol. 10(1-2), pp. 31-42.

Umbreit, M and Coates, R 1992, Victim Offender Mediation: An Analysis of Programs in Four States of the U.S.: Executive Summary, University of Minnesota Center for Restorative Justice and mediation, St. Paul.

UNDP 2002, Human Security in Bangladesh: In Search of Justice and Dignity, Dhaka.

UNICEF 2004, Child Protection - A handbook for parliamentarians, Switzerland.

Wahhab, M A 2009, 'Gram Adalat in Bangladesh: Theory and Practice', in Singh, A and Zahid, N A (eds.), Strengthening Governance through Access to Justice, PHI Learning Pvt Ltd, New Delhi, pp. 17-26.

Walker, K 1998, 'Jurisprudential and Ethical Perspectives on the Best Interests of Children', Interchange, vol. 29(3), pp. 287-308.

Whyte, B 2004, 'Effectiveness, Research and Youth Justice', Youth Justice, vol. 4(1), pp. 3-21.

Weitekamp, E G M and Kerner, H 2002, Restorative Justice: Theoretical Foundation, Willan Publishing, Devon.

World Bank, 'Framing Local Justice in Bangladesh', background paper for the National Workshop on Local Justice Systems in Bangladesh organized by the World Bank and Bangladesh Legal Aid and Services Trust (BLAST) held on May 11-12 at LGED Auditorium, Dhaka.

Zehr, H 1990, Changing Lenses: A New Focus for Crime and Justice, Herald Press, Scottsdale. 